\title{
The White Lie of Persuasive Communication
}

\section{Jaime Bergum}

A breaking news notification pinging onto your phone's lock screen piques your interest: "Politician conned by his own rhetoric?" A frenzied read into the story reveals that a well-liked, long-time, local MLA had been completely blind-sided and deceived by his speech writer who, while writing for the MLA, was simultaneously_and covertly_writing for his toughest political opponent. At a rally on the issue of decreased healthcare spending and support for healthcare workers, the writer had cunningly written the MLA's speech with misinformed exaggerations and statements with underlying sarcasm that demonized healthcare workers for their selfishness in asking more from a government that was already pushing limits. His speech neglected statistics and figures, thus tarnishing any logical appeal his words had; it was also devoid of emotion, insinuating that the rally was a misuse of time in the first place-to his point, healthcare workers had picketed many a time before with no resolve, and it was sure to happen again. The MLA had backed himself into a quickly closing rhetorical trap that saw his reputation and credibility crumbling. Opposite, his opponent delivered a stunningly crafted presentation that embellished support for healthcare workers and commended their impressively valiant and ongoing efforts. Playing into emotions and reasoning, the opponent represented himself as a sincere, wellintentioned, trustworthy leader. Though an extreme example, this narrative evidently depicts how rhetoric is used ethically and unethically, and how ethical and unethical means of rhetorical speech change the evaluation and interpretation of messages. The existence and use of rhetoric are simplified as such: in the hands of the right-minded, well-intended people, rhetoric is entirely ethical and seeks no intended harm to anyone. Contrary, rhetoric becomes unethical when it is used to initiate moral harm.

The following is an insight into the ethical and unethical uses of rhetoric and raises questions of the innate rhetorical ability one is born with, yet how we might not realize the advantageous utilisation of this speech skill. The direction of thinking is guided by the question: can rhetorical speech indeed be labelled as distinctly ethical or unethical if orators are unconsciously unaware of their rhetoric? Establishing a brief history of rhetoric in Ancient Greece, the first definitions of rhetoric as taught separately by Aristotle and the Sophists are compared as the varying ethical nature of rhetoric and its effects are revealed. Next, the definition of rhetoric as a learned and intensely practiced oratory skill raises the question of whether learning rhetoric must always be a deliberate choice, or if the skills of persuasion are wired into human nature? The innateness of rhetoric questions how rhetorical speech is indeed labelled as distinctly ethical or unethical if orators are unconsciously unaware of their rhetoric. Subsequently, if it is happenstance that humans come to learn and practice a form of rhetoric as driven by human nature, competition, and personal satisfaction without malicious intent, how manipulation, persuasion, and deceit come to be known as negative, merciless acts that imply a cruel outcome? By this nature, it becomes evident not only that rhetoric is seen as distinctly positive and ethical in the hands of right-minded people, but that framing draws a fine line between what is perceived as ethical or not, thus making it appear that even in the hands of

Vol. 5(1) | DOI: https://doi.org/10.31542/muse.v5i1.2039 


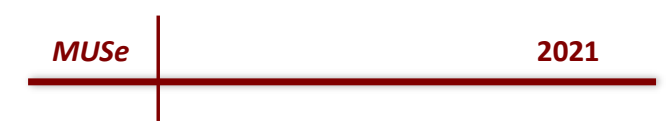

right-minded people and conventionally trustworthy sources, rhetoric can backfire; rather than thoughtfully meditated persuasion, it becomes a manner of emotional manipulation caused by exaggerated misinformation. Finally, when examining rhetoric in a post-truth political climate, and as used by the likes of Donald Trump, does it convey absolute or misconstrued truth?

The art of rhetoric is a form of spoken or written discourse used strategically to inform, persuade, motivate, or exert an effect on an audience, whether that audience is one person or many (Corbett \& Connors, 1999, p. 1). Rhetorical speech therefore refers to methods of persuasion achieved through the use of special and common topics, rhetorical canons and kinds, rhetorical appeals, syllogisms or enthymemes, rhetorical schemes and tropes, and the formulaic arrangement of rhetorical arguments. Rhetoric and persuasion are commonly associated with politics and governance. Corax of Syracuse, the inventor of rhetoric and the common topics, was the first to use a form of rhetoric as a lawyer would today and noticed that sound arguments followed a specific pattern. Rhetoric became commonplace in ancient Greece due in part to Athenian democracy wherein males were "marshaled" into politics, and "every Athenian man had to be ready to stand in the Assembly and speak to persuade his countrymen to vote for or against a particular piece of legislation" (McKay \& McKay, 2020, para. 3). Members of the Athenian Assembly were judged on their rhetorical ability and inherent persuasive skill in successfully, or maybe not so, motivating their audience. After Corax, rhetoric was taught by Sophists, known as "the wise ones"-from the Greek "noun sophia, 'wisdom' or 'learning' (Taylor \& Lee, 2020, para. 1)—notably Gorgias and Isocrates, who travelled between Athenian cities to teach young men public speaking and argumentation. The Sophists developed the presentation and style aspect to rhetoric and "prided themselves on their ability to win any debate on any subject even if they had no prior knowledge of the topic through the use of confusing analogies, flowery metaphors, and clever wordplay" (McKay \& McKay, 2020, para. 5). In ancient Greece, "a 'sophist' was a man who manipulated the truth for financial gain" (McKay \& McKay, 2020, para. 6).

However, the Sophists' definition and utilisation of rhetoric was criticized by classic philosophers like Aristotle, who "defined rhetoric as 'the faculty of discovering all the available means of persuasion in any given situation" (Corbett \& Connors, 1999, p. 1). Thus, as written by Corbett and Connors, "the effects of rhetoric acting as a form of persuasion" in addition to Aristotle's definition of rhetoric, seeks to "comprehend not only those modes of discourse that are 'argumentative' but also those 'expository' modes of discourse that seek to win acceptance of information or explanation (Corbett \& Connors, p. 1). As evidenced by the Sophists' and Aristotle's opposing definitions of rhetoric, its intended purpose as ethical or unethical becomes a contradiction. While both definitions seek acceptance of information, the method through which acceptance is achieved reveals the ethics (or lack thereof) of the message.

Rhetoric and the art of persuasion are unrivaled oratory skills in any century-whether consciously, or not. Every day, harmless uses of rhetoric are not unethical. Think of rhetoric in this sense as the shameless, hopeful, white lie of persuasive communication. This rhetoric happens without people even realizing they're speaking in centuries-old, politically minded patterns. And it's not with malicious intent or to convey trickery or mind games. Every day rhetoric appears almost innate to our very being. It's not a skill we use to change a person's opinion with unethical intent or to spread misinformation and create anarchy. In fact, it's very much happenstance that a person comes to learn and use rhetoric on their own without making 


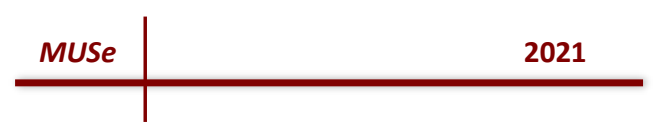

a deliberate choice to enroll in a rhetoric course. Whether labelled as innocently intended persuasion, or a harmlessly child-like mind game, some subdued form of rhetoric exists innately as part of human nature, meaning that as communicators, we do not always need to seek out a place to learn it. However, to both to learn rhetoric ethically, and to understand when someone is using rhetoric unethically against you, requires greater skill and deliberate practice that human nature allows.

Considering the Sophists' use of rhetoric, manipulation for financial gain would seem unethical. And if rhetoric has been used as a menacingly persuasive tactic since its declaration as a form of speech art, who's to say its canny beginnings haven't influenced its use yet today? Rhetoric, as a form of persuasion, involves a necessary degree of manipulation and deception. But somewhere along the way, all three of those words-persuasion, manipulation, and deception-adopted a negative connotation. As if to be manipulated, or persuaded, or deceived was an inherently terrible thing, and whoever manipulated, persuaded, or deceived you was an inherently terrible person. Must manipulation and persuasion always be classified as unlawfully motivated forms of communication, therefore implying that rhetoric itself is indeed unlawfully, ulterior motively unethical? The difference lies here-persuasion is motivated not by deciding to persuade, but by a desire to turn opinions through cause and effect.

One need not be a Greek scholar, or a scholar in training, to use rhetoric. You likely use rhetoric without internalizing that you are using it or deliberately choosing to make rhetorical statements. Basic argumentation and persuasive skills appear not only to be a part of human nature but instill in us prideful satisfaction when we know we've delivered a tactful argument that our opponent cannot refute. The human desire for competition is the driver of innate rhetorical ability. A child who begs his or her parents for a puppy uses rhetorical skills to make the argument as convincing as possible. The child asks for a puppy under the guise it will be "good for me to learn what it's like to have significant responsibility." That is persuasive rhetoric. The child will promise to take the dog for walks every day, feed it, play with it, and clean up after any accidents. The child might go as far as to use emotional tactics and say, "A puppy will teach me responsibility, and the puppy will be my life-long best friend and help me feel safe and protected." With teary eyes and some sniffles, rhetorical appeal and pronuntiatio are executed perfectly by an eight-year-old. And if a child can use it, then rhetoric must be easier to understand than the rules and patterns of classical Greek rhetoric portray. Parents harmlessly use persuasion to teach their children to eat their vegetables before they can have ice cream. Popeye the Sailor is a rhetorical symbol that shows kids and adults that you'll grow big and strong if you eat your spinach. It's not unethical to use rhetoric to teach children how to eat healthy and create lifelong healthy habits.

Ethical uses of rhetoric involve framing and how a speaker chooses to present their argument-though as will be discussed later, a fine line separates what is deemed ethical and not. Resulting from the onset of the coronavirus pandemic in 2020, both big and small name employers were forced to cut salaries and employees' wages due to revenue losses. As reported by Wayland (2020) for CNBC, General Motors, a large global vehicle manufacturing company, made the decision to "temporarily" cut salaries of " $20 \%$ [of its] entire salaried workforce - about 69,000 employees... to save cash to weather the coronavirus crisis" (Wayland, 2020, para. 1). In addition, for employees that could not work from home, the company introduced a "salaried downtime paid absence" in which these workers would still 


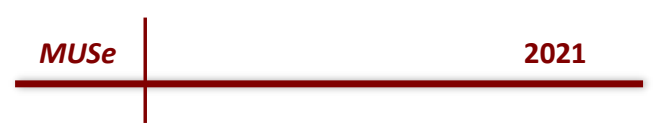

"receive $75 \%$ of their pay, keep seniority and retain health benefits" (Wayland, 2020, para. 3). High level "white-collar" executive employees faced a " $20 \%$ salary deferral [and faced] also taking cuts of $5 \%$ or $10 \%$ to their cash compensation" (Wayland, 2020, para. 4). By first framing the salary cuts as temporary, GM cushions the fact that they are struggling financially, though they reassure employees that there is an end in sight despite uncertainty of knowing exactly when that will be. Paying attention to the unique circumstances of different levels of employees - blue versus white-collar workers - and adapting financial cuts to suit and maintain the quality of life of these employees, whether they are manufacturers or executives, is also an ethical use of ethos, pathos, and logos. It shows GM's consideration for the well-being of their employees, their commitment to surviving through the pandemic and coming out afloat, and shows that ultimately, cutting wages or skipping on bonuses for one year are not punishments. The message pertains to the benefit of the collective group and the company itself at the cost of a small (temporary) sacrifice.

Rhetoric is ethical at its most basic level. Is it likely that everyone in the modern age knows exactly what rhetoric is, where it originated, or what rhetorical argumentation entails beyond the sense of argumentation that is innate to human nature? Possibly not, however, could it be a case of 'buyer beware'? Even in moments where rhetoric is used to cover a blunt truth or save face in a moment of doubt, would it not be beneficial for everyone to have some degree of rhetorical knowledge to determine well-intentioned truth from rhetorical strategy? Extensive rhetorical knowledge aside, rhetoric to aid in softening truth and saving face is where rhetoric in the $21^{\text {st }}$ Century has gone right, and where rhetoric has become our reality and our dream. Rhetoric is used with good intention to produce desired results. Rhetoric does not have to be used with malice as blind manipulation to be only unethical or contrived from immoral principles. As with many things, in the hands of the right-minded, well-intended people, rhetoric is entirely ethical and seeks no intended harm to anyone.

The principles of rhetoric border a fine line between what is considered ethical or not, thus making it easy to use rhetoric unethically. From its origin in Ancient Greece, the intended uses of rhetoric have been greatly contested as used and taught by Aristotle and the Sophists. As stated previously, Aristotle viewed rhetoric as an argumentative and expository method of persuasion. Persuasion in this logic would rely on statement of all facts to visualize and comprehend an entire scenario and each of the possible outcomes before settling on the desired end goal of persuasion. Now, recall the Sophists who used rhetoric more as a display of showmanship and spectacle to prove they could argue and win a debate on any topic using confusing rhetorical mind games akin to mental manipulation. Is this to say that the end goal of a rhetorical argument must not be to initiate moral good if the means by which a person who uses rhetoric unethically —as the Sophists did-are unethical? Does method define the madness?

Since 2020, the coronavirus pandemic has been used as a rhetorical scapegoat to deflect blame and make emotionally and logically appealing claims as to why the world stood at a standstill. Shortages to food, resources, and work, why businesses were suffering and forced to reduce salaries and furlough employees, and how the media took existing overwhelming fear and panic regarding the pandemic and exacerbated those feelings. While the media played off peoples' fears and anxiety about the everchanging gravity of the pandemic, an opposite reaction ensued. Instead of the emotional manipulation causing people take this worldwide panic more 


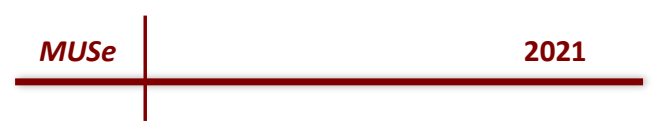

seriously, people grew fed-up and grew to resist and deny the existence of the virus and the importance of the transmission-minimizing efforts that were put in place. The idea that "COVID19 is no worse than the common cold" (Dickson, 2020) overshadowed the implicit necessity of COVID-19 safety measures, including safe social distancing, wearing masks, and avoiding unnecessary travel. One of the biggest misconceptions alone was that masks weren't needed to protect yourself or others from contracting the virus. Early in the pandemic it was not required that the general population wear a face covering in public unless a person was developing COVID symptoms. Though, upon developing a greater scientific understanding of COVID-19 transmission, the consensus amongst global health authorities was that face masks were in fact effective and limited person-to-person transmission. Further, masks were proven especially vital when health officials discovered the virus could be transmitted through asymptomatic carriers. Silent transmission of the virus to vulnerable demographics informed clear urgency to mandate that all members of a population wear a face covering in public. However, in parts of the United States in particular, residents saw forced face coverings as a violation of their natural born right to freedom and merely a ploy of corrupt government control and manipulation. Though it was for their own safety, the rhetoric and spectacle of the pandemic from the beginning-specifically the toilet paper fiasco and COVID-19 scapegoating for all delays and inconveniences, which again were both magnified by the media-initiated a moral harm to those who grew to deny the existence of any pandemic. Media manipulation and misinformed pandemic rhetoric questioned the legitimacy of COVID-19 entirely. As of July 2021, the total number of COVID-19 cases across the U.S. reached 35 million with the number of COVID-19 deaths totalling 613, 000 (Google Statistics, 2021). For context, the total recorded population of Edmonton in 2019 was 972,223 people (Mertz, 2019, para. 1). The number of COVID deaths in the U.S. equates to over half the population of Edmonton, yet the "U.S. public health response to COVID-19 has been dismal, characterized by anti-mask behavior, antivaccine beliefs, [and] conspiracy theories about the origins of COVID-19" as perpetuated by media fear-mongering and emotional manipulation. (Miller, 2020, para. 1).

Rhetoric becomes unethical when and if it is used explicitly to initiate moral harm. When rhetoric goes wrong, expert rhetoricians use skillful persuasion, manipulation, or deception on others who don't know or understand what rhetoric is and are naïve to rhetorical strategy and how their opponent (the expert rhetorician) will play into that naivety and lack of rhetorical knowledge. Rhetoric becomes a living nightmare when it allows the distinguished orator to make blanket statements that appeal to larger masses in the temptation of positive reinforcement and instant gratification from the audience. However, there is no merit to what is said.

Overshadowing contrived misinformation with rhetorical metaphors, analogies, and emotional tactics is using rhetoric unethically as a means to fulfill personal satisfaction of engaging and/or winning over an audience (Merhodin, 2016). The result is failing to communicate or deliver a message for any other reason than to prove skill as a convincing and effective persuader.

In a post-truth society, where "objective facts' are less influential in shaping public opinion than appeals to emotion and personal belief' (Fridlund, 2020, p. 217), the "dissemination of alternative facts have permeated public rhetoric" (Twal, 2019, p. 116). What this means is that especially in the political realm, statements of toxic rhetoric, otherwise known as manufactured claims and misinformation or conspiracy hoaxes, have long disturbed and further "polarized, fragmented, and broken" political terrain, making it even more challenging "to 


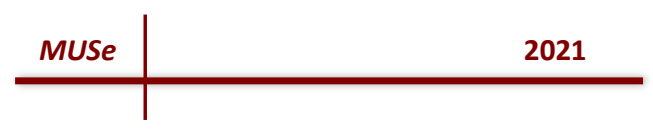

find common ground with those with whom we disagree" (Twal, 2019, p. 117). To find common ground in any relationship inside and outside of politics requires ethical attunement, defined by "the reactiveness we have to another person...the process by which we form relationships" (Momentous Institute, 2017). Unethical rhetoric disturbs the relationship forming process, leading to misaligned common ground and views.

Toxic persuasive discourse is recognized as "incivility, hate speech, eliminationist rhetoric, venomous speech, and outrage discourse" and are deemed so by the nature in which they harm others through "dishonesty, unaccountability, demonization, violence, denial, and poverty of spirit" (Duffy, 2012, as cited in Twal, 2019, p. 117). Misinformation, exaggerated statements, falsehoods, and unreputable claims that are dispersed as truth require a critical eye to determine their validity as ethical or moral statements. Infamous toxic rhetorician former president Donald Trump is known for his viral accusatory rhetoric. Jennifer Mercieca, an Associate Professor of Communication at Texas A\&M University and author of the book Demagogue For President: The Rhetorical Genius of Donald Trump, has compared Trump's use of rhetoric to that of a "dangerous demagogue" who uses rhetoric as a measure to "prevent the country from holding him [Trump] accountable" (Mercieca, 2020). In her book she defines the Greek term demagogue as "leader of the people," and further categorizes demagogues into good and dangerous. The difference being whether or not good leaders or dangerous leaders are held accountable for their actions (Mercieca, 2020). In a separate interview, Mercieca is quoted saying that Trump was successful with his toxic rhetoric because "he communicates like a demagogue and not like a president... he took advantage of [pre-existing] distrust and polarization and frustration, and he used rhetorical strategies that were designed to make all of those things worse" (Shapiro, 2021).

Of the rhetorical strategies used by Trump to facilitate toxicity and fuel controversy and reaction to his statements are "threats of force and intimidation" as seen in interviews where Trump has deliberately ignored questions asked of him and instead attacked and turned attention back to the interviewer "to show his audience how phony the interview is" thus, "signaling to his followers that no one should trust the media" (Shapiro, 2021). Trump was also seen to be "much more eager than any of his predecessors to dehumanize his opponents" (Shapiro, 2021), which in doing so supports displays of hate speech, incivility, demonization, and misinformation that fabricate an environment of toxic, inflammatory, venomous rhetoric. Another rhetorical strategy used by Trump was a type of irony called paralipsis "to pass over some matter, yet [manage] to subtly to reveal the manner anyway" (Corbett \& Connors, 1999, p. 406), or in other words, "I'm not saying; I'm just saying" which for a speaker, becomes a convenient "plausible deniability to assert that they didn't actually say some controversial thing or that they were merely joking or being sarcastic" (Mercieca, 2020). In Trump's case, this allowed him to "spread rumor and innuendo and to give a 'backstage' or 'real' view of what he supposedly really thinks" for example in the way of "repeatedly amplified racist white nationalist content on his Twitter feed while denying that he agreed with them" (Mercieca, 2020). Trump hid behind skewed rhetoric to discredit his opponents, the public, and any outside opinions that questioned his own ethics or morals. Trump becomes a clear example of how rhetoric in the hands of the wrong person can be used to evade or misconstrue meaning.

When used ethically, rhetoric is a skill that delivers strategic, sound, indisputable arguments to an audience. Rhetorical persuasion used as means of winning over is regarded 
"primarily as an accomplishment or achievement: one's action has had an effect, and ordinarily, the action was designed to 'produce' the effect" (Diggs, 1964, p. 360). Persuasion is motivated not by deciding to persuade, but by a desire to turn opinions through cause and effect. It is to this length that persuasion becomes unethical when a speaker becomes less concerned with an explanation of point of view and rhetorical dispositio, and more concerned with the end motivewhich is successfully turning the audience's point of view to support the speaker's own beliefs without question. Rhetorical messages focused on the end motive dismiss ethics and morality and leave little room to refute or consider opposing viewpoints. Audiences are made aware of one primary opinion that is laid out to overshadow anything else. Even if an argument is unethical and immoral, convincing-enough facts, embellished presentation skills, and the overall presence of the speaker will win an audience's attention. That is rhetorical success and nightmare.

"Rhetorical choices are ultimately ethical decisions, always with motive, and always with consequences" (Hardesty, 2013, p. 54). We come to the point again where we ask if rhetoric and persuasion, rhetoric and manipulation, or rhetoric and deception are always guaranteed inherently terrible things? Or is it just when in the hands of someone with misaligned morals that we should fear the consequences of rhetorical speech? Rhetoric as a form of discourse should be used to persuade an audience intellectually and factually. The manner in which a rhetorical argument is conducted defines the ethics of it, not the subject of the argument. Too often does it seem that mindfully skewed rhetoricians rely on emotional triggers, emotional scapegoats, and confusing language to pin their audience for, or against, a particular point of view. Rhetoric in the age of $21^{\text {st }}$ Century technological misinformation should focus on statistics, proofs, testimony, logic, and reason. Persuasive manipulation of the masses is the fault of whoever abuses rhetorical skill to their advantage. When rhetoric becomes blind, vengeful manipulation, it also becomes our living nightmare. All too easily does rhetoric entrust abuse of power, and all too easy does the nature of post-truth society surrender to the spitefully twisted metaphorical language of modern rhetoric. 


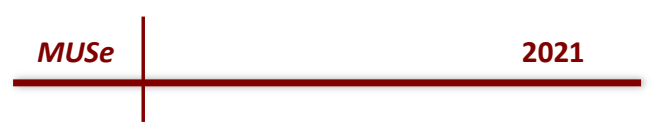

\section{References}

Corbett, E.P.J. \& Connors, R. J. (1999). Classical rhetoric for the modern student. Oxford University Press.

Dickson, E. (2020, March 18). Coronavirus is spreading -- and so are the hoaxes and conspiracy theories around it. [Web article]. Retrieved from: https://www.rollingstone.com/culture/culture-news/coronavirus-china-bat-patentconspiracy-theory-942416/

Diggs, B. J. (1964). Persuasion and ethics. The Quarterly Journal of Speech. 50(4), 359373, https://doi.org:10.1080/00335636409382679

Fridlund, P. (2020). Post-truth politics, performatives and the force. Jus Cogens 2, 215-235. https://doi.org/10.1007/s42439-020-00029-8

Google Statistics (2021). United States coronavirus disease. [Web search]. Retrieved from: https://www.google.com/search?q=Coronavirus+United+States

Hardesty, K. S. (2013). An(other) rhetoric: Rhetoric, ethics, and the rhetorical tradition. Scholar Commons: Graduate Theses and Dissertations. http://scholarcommons.usf.edu/etd/4898

McKay, B. \& McKay, K. (2020, October 7). Classical rhetoric 101: A brief history. [Webpage]. Retrieved from: https://www.artofmanliness.com/articles/history-of-rhetoric/

Mercieca, J. (2020). A field guide to Trump's dangerous rhetoric. [Webpage article]. Retrieved from: https://theconversation.com/a-field-guide-to-trumps-dangerous-rhetoric-139531

Merhodin. (2016, May 3). Concept definition: Unethical rhetoric. [Webpage]. Retrieved from: https://delicateethics.wordpress.com/2016/05/03/concept-definition-unethicalrhetoric/\#: :text=On\%20a\%20larger\%20scale\%2C\%20rhetoric,mentioned\%20by\%20Ari stotle\%20and\%20Duffy.

Mertz, E. (2019, September 06). Census reveals Edmonton's population has TOPPED 972,000. [Web article]. Retrieved from: https://globalnews.ca/news/5861019/census-edmontonpopulation-2019/

Miller, B.L. (2020). Science denial and covid conspiracy theories-lessons from clinical Disease about possible neurophysiological mechanisms. [Web article] Retrieved from: https://jamanetwork.com/journals/jama/fullarticle/2772693

Momentous Institute. (2017, February 27). What is attunement? [Webpage]. Retrieved from: https://momentousinstitute.org/blog/what-is-attunement

Shapiro, A. (2021, January 19). How president Trump's rhetoric has affected U.S. politics. [Radio broadcast transcript]. NPR. https://www.npr.org/2021/01/19/958472423/howpresident-trumps-rhetoric-has-affected-u-s-politics

Taylor, C.C.W, \& Lee, M. (2020). The sophists. Standford Encyclopedia of Philosophy. [Webpage database]. https://plato.stanford.edu/entries/sophists/ 
Twal, E. C. (2019). Provocations of virtue: Rhetoric, ethics, and the teaching of Writing. Community Literacy Journal, 14(1), 116-120.

https://doi.org/10.1353/clj.2019.0022

Wayland, M. (2020). GM temporarily cuts pay by $20 \%$ for 69,000 salaried workers amid coronavirus pandemic. [Web article]. CNBC. https://www.cnbc.com/2020/03/26/gmtemporarily-cuts-pay-by-20percent-for-69000-salaried-workers-amid-coronaviruspandemic.html 